\title{
PENGARUH VARIASI JENIS LIMBAH KULIT PISANG DENGAN KOTORAN SAPI TERHADAP HASIL PRODUKSI BIOGAS
}

\author{
THE EFFECT OF VARIATIONS IN TYPES OF BANANA PEEL WASTE \\ AND COW DUNG ON BIOGAS PRODUCTION
}

\author{
Arlina, Jeanette Mutiara P. Saudale, Dwi Ana Anggorowati* \\ Program Studi Teknik Kimia, Fakultas Teknologi Industri, Institut Teknologi Nasional (ITN) \\ JI. Bendungan Sigura-gura 02, Malang, 65145, Indonesia \\ *anggoro_dwiana@yahoo.com
}

\begin{abstract}
Abstrak
Kulit pisang merupakan bahan buangan (limbah buah pisang) yang cukup banyak jumlahnya sehingga dapat dimanfaatkan sebagai bahan baku pembuatan biogas. Penelitian ini bertujuan untuk mengetahui pengaruh perbedaan variasi limbah kulit pisang dan kotoran sapi terhadap biogas yang dihasilkan. Variasi yang digunakan yaitu campuran kotoran sapi dengan kulit pisang ambon, kepok dan raja dengan perbandingan berturut-turut 1:7, 1:5, 1:4. Campuran bahan dimasukkan ke dalam bioreaktor sederhana yang kedap udara dan selanjutnya dilakukan tahap proses fermentasi selama 15 hari. Kemudian dilakukan pengecekkan suhu, dan volume gas yang dihasilkan setiap hari serta dilakukan pengecekkan terhadap $\mathrm{pH}$ akhir. Dari hasil penelitian didapatkan volume gas terbanyak yaitu $409 \mathrm{~mL}$ pada hari ke-9 yaitu dari campuran kotoran sapi dan kulit pisang raja dengan perbandingan 1:4. Untuk nilai $\mathrm{pH}$ diawal terhadap semua variasi kulit pisang berada pada range 6,9-7,5 dan untuk nilai $\mathrm{pH}$ akhir berada pada range 5,1-5,8 hal ini berarti ketiga bioreaktor menunjukkan $\mathrm{pH}$ akhir dalam keadaan asam. Kemudian untuk uji nyala di dapat hasil uji nyala pada R1 (kulit pisang ambon) menghasilkan nyala api biru kemerahan kemudian pada R2 (kulit pisang kepok) dan R3 (kulit pisang raja) menghasilkan nyala api biru, berdasarkan hasil peneletian yang sudah dilakukan dapat ditarik kesimpulan bahwa produksi biogas terbaik diperoleh dari variasi kulit pisang raja.
\end{abstract}

Kata kunci: Biogas, Fermentasi Metanogenik, Limbah Kulit Pisang, Kotoran Sapi

\begin{abstract}
Banana peel is a waste material (banana fruit waste) which is quite large in number so that it can be used as a raw material for making biogas. This study aims to determine the effect of different variations of banana peel waste and cow dung on the biogas produced. The variation used was a mixture of cow dung with banana skins of Ambon, Kepok and Raja with successive ratios of 1: 7, 1: 5, 1: 4. The mixture of ingredients is put into a simple airtight bioreactor and then the fermentation process is carried out for 15 days. Then check the temperature and volume of gas produced every day and check the final $\mathrm{pH}$. The results showed that the highest volume of gas was $409 \mathrm{~mL}$ on the 9th day, namely from a mixture of cow dung and plantain skin with a ratio of 1: 4. The initial $p H$ value for all variations of banana peel is in the range of 6.9-7.5 and for the final $p H$ value is in the range 5.1-5.8, this means that the three bioreactors show the final $p H$ is acidic. Then for the flame test, the results of the flame test on R1 (Ambon banana peel) produce a reddish blue flame then $R 2$ (Kepok banana peel) and $R 3$ (plantain peel) produce a blue flame, based on the results of the research that has been done, conclusions can be drawn that the best biogas production is obtained from the variety of plantain peels.
\end{abstract}

Keywords: Biogas, methanogenic fermentation, banana peel waste, cow dung 


\section{Pendahuluan}

Saat ini kebutuhan bahan bakar minyak dari waktu ke waktu semakin meningkat, yang mana mengakibatkan meningkatnya harga minyak mentah dan diiringi dengan subsidi BBM yang tinggi. Oleh karena itu, perlu adanya kajian terhadap energi alternative yang cocok dan dapat di produksi di Indonesia (Megawati, 2015). Solusi yang dapat digunakan adalah dengan memanfaatkan limbah dalam pembuatan biogas, yang mana biogas disini merupakan energi yang layak digunakan baik secara teknis, sosial, maupun ekonomis. Adapun limbah peternakan merupakan salah satu sumber bahan utama pembuatan biogas (Mara, 2012).

Biogas adalah salah satu energi alternative yang cocok dan dapat di produksi di Indonesia. Yang mana biogas ini merupakan suatu gas yang dihasilkan secara mikrobiologi anaerobik dari limbah organic. Pada biogas terdapat campuran metana $\mathrm{CH}_{4}(55-70 \%), \mathrm{CO}_{2}(25-50 \%), \mathrm{H}_{2} \mathrm{O}(1-5 \%), \mathrm{H}_{2} \mathrm{~S}(0-0,5 \%), \mathrm{N}_{2}(0-5 \%)$ dan $\mathrm{NH}_{3}(0-0,05 \%)$ (Herawati, 2010).

Pembuatan energi alternative biogas relative mudah, karena dapat menggunakan bahan organik sebagai bahan dasarnya, dengan mengfungsikan drum bekas sebagai unit reaktor biogas, dan untuk membantu agar proses pendegrasian sampah organik berjalan dengan cepat, dilakukan penghalusan atau sampah organik terlebih dahulu dicincang sebelum memasuki reaktor (Sutrisno, 2010).

Adapun kulit pisang yang merupakan bahan buangan (limbah buah pisang) yang cukup banyak jumlahnya. Pada umumnya kulit pisang belum dimanfaatkan secara nyata dan hanya di buang sebagai limbah organik saja atau digunakan sebagai makanan ternak seperti kambing, sapi, dan kerbau (Bahri, 2018).

Penelitian sebelumnya yang membuat biogas dari kulit pisang yang berjudul "Pengaruh Ampas Kelapa dan Kulit Pisang Terhadap Produksi Biogas dari Kotoran Sapi” oleh Adam Fairuz, dkk (2015). Adapun variable yang digunakan yakni jenis limbah yang digunakan (kulit pisang dan ampas kelapa), dan dibuat 6 perlakuan dengan perbandingan antara kotoran sapi, kulit pisang dan ampas kelapa. Jugs variable lainnya adalah komposisi biogas yang dihasilkan, pengukuran $\mathrm{pH}$ diawal dan di akhir, waktu fermentasi selama 1-30 hari. Hasil yang di dapat pada pembuatan biogas dengan 6 perlakuan, 5 diantaranya (A, B, C, D, E) memiliki C/N rasio di bawah standar 20-30 dan hanya perlakuan $\mathrm{F}$ yang memiliki $\mathrm{C} / \mathrm{N}$ raso dalam kisaran standar. menghasilkan komposisi gas sebesar 54,03\% volume gas. Adapun total produksi biogas berkisaran antara 5738 hingga $7918 \mathrm{ml}$, dengan uji nyala hanya pada perlakuan F yang berhasil menyala dengan api berwarna biru.

Oleh karena dari hasil beberapa penelitian terdahulu tentang pemanfaatan limbah kulit pisang dan kotoran sapi dalam proses pembuatan biogas, maka kami hendak melakukan penelitian tentang pembuatan biogas dari kotoran sapi dengan variasi pemberian beberapa jenis limbah kulit pisang yaitu kulit pisang ambon, kapok dan raja yang dilakukan secara anaerobik.

\section{Kulit Pisang}

Pada umumnya kulit pisang belum dimanfaatkan secara nyata dan hanya di buang sebagai limbah organik saja atau digunakan sebagai makanan ternak seperti kambing, sapi, dan kerbau (Bahri, 2018).Limbah kulit pisang bisa menjadi permasalahan limbah di alam karena akan meningkatkan keasaman tanah dan mencemarkan lingkungan (Retno, 2011). Maka dari itu kulit pisang dapat menjadi pertimbangan sebagai bahan baku biomassa untuk produksi energi.

Tabel 1. Karakteristik Komposisi Bahan Kimia Beberapa Jenis Kulit Pisang

\begin{tabular}{|l|l|l|l|}
\hline \multirow{2}{*}{ Kimia } & \multicolumn{3}{|c|}{ Komposisi Jenis Pisang (\%) } \\
\cline { 2 - 4 } & Ambon & Kepok & Raja \\
\hline Kadar Air & 69,93 & 69,45 & 61,60 \\
\hline Kadar Abu & 3,22 & 2,56 & 4,23 \\
\hline Kadar Lemak & 1,38 & 0,98 & 3,41 \\
\hline Protein & 1,30 & 1,50 & 3,12 \\
\hline Kadar & 12,02 & 10,44 & 9,55 \\
\hline Serat Karbohidrat & 25,09 & 25,35 & 27,64 \\
\hline Pektin & 1,00 & 1,08 & 1,08 \\
\hline
\end{tabular}

(Proverawati, 2019).

\section{Kotoran Sapi}

Limbah ternak yang merupakan sumber mikroorganisme dan mengandung bahan organik yang potensial dapat mencemari lingkungan. Limbah ternak memiliki potensi sebagai sumber energi alternatif yaitu biogas (Lestari, 2016).

Kotoran sapi merupakan substrat yang dianggap paling cocok sebagai sumber pembuat biogas, karena substrat tersebut telah mengandung bakteri penghasil gas metan yang terdapat dalam perut hewan ruminansia. Keberadaan 
bakteri di dalam usus besar ruminansia tersebut membantu proses fermentasi, sehingga proses pembentukan gas bio pada tangki pencerna dapat dilakukan lebih cepat (Irawan, 2016).

Tabel 2. Karakteristik Kotoran Sapi

\begin{tabular}{|c|c|}
\hline Komponen & Massa (\%) \\
\hline Total padatan & $3-6$ \\
\hline Total padatan Volatile & $80-90$ \\
\hline Total kjeldahl nitrogen & $2-4$ \\
\hline Selulosa & $15-20$ \\
\hline Lignin & $5-10$ \\
\hline Hemiselulosa & $20-25$ \\
\hline
\end{tabular}

(Prihutama, 2017).

\section{Proses Pembentukan Biogas}

Penggunaan metode anaerobik adalah metode yang paling sering digunakan karena menghasilkan gas metana dan sisa limbah cair yang kaya nutrisi seperti nitrogen dan fosfor (Fitri 2018). Proses penguraian secara anaerobik terdiri dari beberapa tahapan, yaitu :

\section{a. Hidrolisis}

Hidrolisis adalah penguraian bahan-bahan organik mudah larut dan pencernaan bahan organik yang kompleks menjadi bentuk sederhana (Dianawati, 2015). Bahan-bahan organik seperti selulosa, polisakarida dan lemak diubah menjadi bahan yang larut air seperti karbohidrat dan asam lemak (Prihutama, 2017). Pada tahap hidrolisis, mikroorganisme yang berperan adalah enzim ekstraselular seperti selulose, amilase, protease dan lipase (Suyitno, 2010).

Reaksi :

$$
\begin{array}{ccc}
\left(\mathrm{C}_{6} \mathrm{H}_{10} \mathrm{O} 5\right) \mathrm{n} \\
\text { Selulosa }
\end{array} \underset{\text { Air }}{\mathrm{n} \mathrm{H} \mathrm{H}_{2} \mathrm{O}} \longrightarrow \begin{gathered}
\mathrm{n} \mathrm{C}_{6} \mathrm{H}_{10} \mathrm{O}_{6} \\
\text { Glukosa }
\end{gathered}
$$

b. Asidogenesis (Pengasaman)

Asidogenesis adalah tahapan dimana produk- produk yang dihasilkan dari proses hidrolisis dikonversi oleh bakteri asidogenik menjadi substrat metanogenik (Clinton, 2015). Pada tahap ini bakteri akan menghasilkan asam yang akan berfungsi untuk mengubah senyawa pendek hasil hidrolisis menjadi asam asetat $(\mathrm{CH} 3 \mathrm{COOH}), \mathrm{H} 2 \mathrm{dan}$ CO2 (Suyitno, 2010). Pada tahap ini Gula sederhana, asam amino, dan asam lemak terdegradasi menjadi asetat, karbondioksida dan hidrogen (70\%) serta menjadi Volatile Fatty Acid (VFA) dan alkohol (30\%) (Megawati, 2015). Tahap ini berlangsung pada suhu $25^{\circ} \mathrm{C}$

Reaksi :

$$
\begin{aligned}
& \mathrm{C}_{6} \mathrm{H}_{12} \mathrm{O}_{6} \longrightarrow 2 \mathrm{C}_{2} \mathrm{H}_{5} \mathrm{OH}+2 \mathrm{CO}_{2} \\
& \text { Glukosa Etanol Karbon dioksida } \\
& 2 \mathrm{C}_{2} \mathrm{H}_{5} \mathrm{OH}+\mathrm{CO}_{2} \longrightarrow 2 \mathrm{CH}_{3} \mathrm{CO}_{2} \mathrm{H}+\mathrm{CH}_{4} \\
& \text { Etanol Karbon dioksida Asam asetat Metana }
\end{aligned}
$$

c. Metanogenesis

Metanogenesis adalah tahapan paling akhir dimana bakteri metanogenik atau bakteri pembentuk metan menghasilkan gas metan, karbondioksida, dan sedikit gas lain (Clinton, 2015). Pada tahap pembentukan gas CH4, bakteri yang berperan adalah bakteri methanogenesis (bakteri metana). Kelompok bakteri metana, yaitu dari jenis methanobacterium, methanobacillus, methanosacaria, dan methanococcus. Bakteri ini membutuhkan kondisi kedap udara dengan temperatur optimum antara $25^{\circ} \mathrm{C}-35^{\circ} \mathrm{C}$ dan Kisaran pH adalah 6,5-7,5 (Suyitno, 2010).

Metanogenesis merupakan langkah penting dalam seluruh proses anaerobik, karena metanogenesis merupakan reaksi biokimia paling lambat. Proses metanogenesis sangat dipengaruhi olehkomposisi bahan baku, perbandingan makanan, temperatur, dan nilai $\mathrm{pH}$,Overload digester dan masuknya oksigen dalam jumlah besar dapat mengakibatkan penghentian produksi metana.

Reaksi :

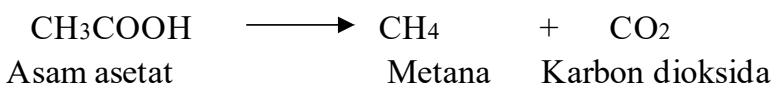

Adapun berikut ini faktor-faktor yang dapat mempengaruhi pembentukan biogas

1. Derejat keasaman $(\mathrm{pH})$

$\mathrm{pH}$ optimal yang dibutuhkan pada pengolahan biogas adalah pada range 6,6 - 7,5 (Yunus, 1991). Setiap mikroba yang terlibat dalam degradasi anaerobic memiliki rentang $\mathrm{pH}$ tertentu agar tumbuh secara 
optimal. pH optimal untuk bakteri asidogen sekitar 6, untuk bakteri asetogen dan metanogen memiliki pH optimal sekitar 7.

2. Suhu

Range temperatur yang digunakan pada digester anaerobik adalah mesofilik $\left(25-40^{\circ} \mathrm{C}\right)$ dan termofilik $\left(50-60^{\circ} \mathrm{C}\right)$. Instalasi biogas menggunakan temperatur mesofilik karena pengoperasiannya relatif lebih mudah. Bila dilakukan pada suhu termofilik, maka harus memiliki kendali temperatur yang ketat.

3. Nutrisi

Biodegradasi yang efektif dan efisien membutuhkan nutrisi seperti nitrogen, fosfor, serta unsur-unsur yang lain dalam jumlah yang cukup. Nutrisi digunakan untuk membangun sel- sel yang membentuk mikrooganisme dan menghasilkan biogas.

4. Keracunan dan hambatan

Bakteri metanogen merupakan miroorganisme yang sangat sensitif terhadap toksisitas. Selain itu, bakteri metanogen juga sensitif terhadap oksigen (Fitri, 2018).

5. Perbandingan $\mathrm{C}-\mathrm{N}$ bahan isian

Rasio C-N adalah perbandingan kadar karbon(C) dan kadar Nitrogen (N) dalam satuan bahan. Semua mahluk hidup terbuat dari sejumlah besar bahan Karbon (C) dan Nitrogen (N) dalam jumlah kecil.

6. Kandungan bahan kering

Bahan isian dalam pembuatan biogas harus berupa bubur. Bentuk bubur ini dapat diperoleh bila bahan bakunya mempunyai kandungan air yang tinggi. Bahan baku dengan kadar air yang rendah dapat dijadikan berkadar air tinggi dengan menambahkan air ke dalamnya dengan perbandingan tertentu sesuai dengan kadar bahan kering bahan tersebut (Wiratmana, 2012)..

\section{Metodologi Penelitian}

Adapun peralatan yang digunakan yaitu, galon, Urine Bag, selang penghubung, termometer, gelas ukur, toples dan $\mathrm{pH}$ meter. Dan bahan yang digunakan terdiri dari kotoran sapi, air, dan limbah kulit pisang (pisang kapok, pisang raja, pisang ambon).

\section{Variabel Penelitian}

- Suhu

: Suhu kamar (antara $\left.20-25^{\circ} \mathrm{C}\right)$

- $\mathrm{pH}$

: 6,6-7,5

- Perbandingan campuran bahan : 1:1:7, 1:1:5, 1:1:4

- Bahan baku yang digunakan : Kotoran sapi dan air

- Jenis limbah

- Waktu fermentasi

: Kulit pisang ambon (R1), kulit pisang kapok (R2), dan kulit pisang raja (R3)

: 1-15 hari

\section{Diagram Alir}

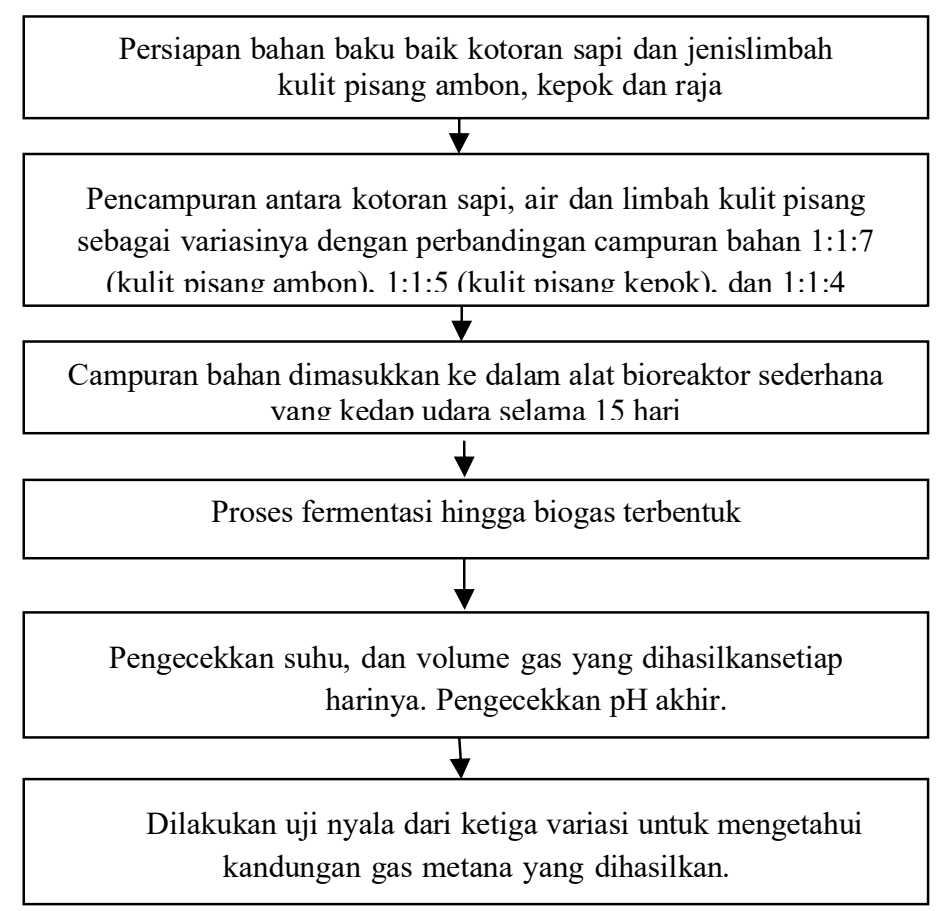




\section{Hasil}

\section{Hasil Analisa Awal C/N}

Berikut ini merupakan tabel kadar $\mathrm{N}$ total, $\mathrm{C}$-organik dan ratio $\mathrm{C} / \mathrm{N}$ yang di dapat dari hasil analisa oleh Balai Pengkajian Teknologi Pertanian Nusa Tenggara Timur.

Tabel 3. Hasil Analisa kadar $\mathbf{N}$ total, C-organik dan ratio $\mathrm{C} / \mathrm{N}$

\begin{tabular}{|c|l|l|l|l|}
\hline No & Sampel & N total (\%) & C-organik (\%) & Ratio C/N \\
\hline 1 & Kulit Pisang Raja & 0,07 & 1,81 & 25,85 \\
\hline 2 & Kulit Pisang Kepok & 0,05 & 2,08 & 41,60 \\
\hline 3 & Kulit Pisang Ambon & 0,04 & 1,63 & 40,75 \\
\hline 4 & Kotoran Sapi & 0,31 & 6,22 & 20,06 \\
\hline
\end{tabular}

Sumber : Balai Pengkajian Teknologi Pertanian Nusa Tenggara Timur

Dari tabel di atas, dapat diketahui perbandingan kotoran sapi dan masing-masing kulit pisang dengan menggunakan perhitungan. Sehingga untuk pebandingan kotoran sapi dan kulit pisang raja di dapat 1:4, kotoran sapi dan kulit pisang kepok di dapat 1:5, kotoran sapi dan kulit pisang ambon di dapat 1:7.

\section{Pengaruh Suhu Terhadap Volume Biogas yang Dihasilkan}

Pada penelitian ini dapat dilihat bahwa pada rentang suhu di ketiga digester tersebut selama waktu fermentasi yakni 15 hari menunjukkan adanya komunitas mikroorganisme dalam digester anaerobik yaitu komunitas mikroorganisme mesofilik dengan range temperature $25-40{ }^{\circ} \mathrm{C}$ (Wiratmana, 2012). Adapun dalam penelitian ini terjadi beberapa kali perubahan suhu yang signifikan seperti pada digester R3 yaitu dari suhu $30^{\circ} \mathrm{C}$ di hari ke-9 yang kemudian turun hingga $28^{\circ} \mathrm{C}$ di hari ke-10, yang mana setelah penurunan ini gas yang dihasilkan tidak lagi bertambah. Menurut Haryanto (2019) bakteri metanogenik sangat sensitif terhadap perubahan suhu, yang mana penurunan $1-2^{\circ} \mathrm{C}$ akan dapat mengakibatkan menurunnya produksi biogas.

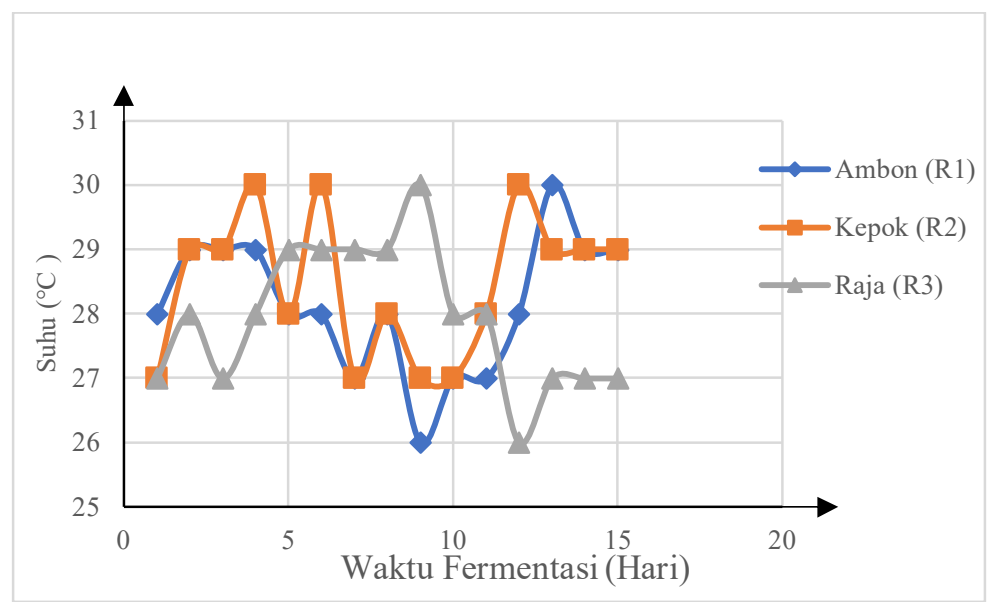

Gambar 1. Hubungan antara suhu dan volume gas yang dihasilkan dari variasi perbandingan jenis kulit pisang dan Kotoran sapi

\section{Pengaruh Lama Waktu Fermentasi Terhadap Volume Biogas yang Dihasilkan}

Penelitian ini menunjukkan bahwa selama waktu fermentasi dari ketiga variasi yaitu R1 (kulit pisang ambon), R2 (kulit pisang kepok) dan R3 (kulit pisang raja) menghasilkan volume gas berturut-turut di hari hari ke8 , ke-7 dan ke-9. Akan tetapi dihari berikutnya volume biogas tidak lagi terbentuk, hal ini menunjukkan bahwa bakteri metanogen dapat berkerja secara efektif di hari ke-7 hingga hari ke-9. 


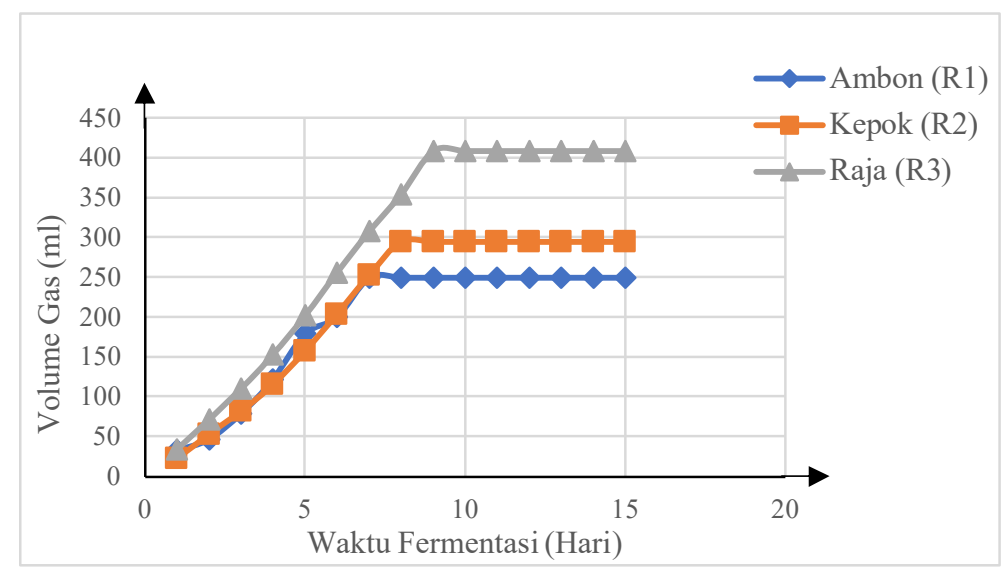

Gambar 2. Hubungan antara volume gas yang di hasilkan dan lama waktu fermentasi dari variasi perbandingan jenis kulit pisang dan Kotoran sapi

Proses fermentasi bakteri pembentukan biogas (metanogen) pada awalnya mengalami masa penyesuaian dengan bahan baku di dalam digester, dan kemudian akan mengalami masa pertumbuhan karena adanya pemanfaatan nutrisi hingga dapat dihasilkan produksi biogas maksimal. Lalu di tahap akhir, fermentasi akan memasuki fase dimana bakteri mulai kekurangan nutrisi dan mengalami kematian sehingga produksi biogas yang terbentuk akan mulai menurun. Selain itu, jumlah volume biogas yang dihasilkan tidak hanya dipengaruhi oleh variasi jenis maupun konsentrasi substrat dan suhu lingkungan saja, akan tetapi juga dipengaruhi oleh faktor lainnya seperti pH substrat, komposisi bahan organik, dan mikroorganisme (Kurniawan 2016).

Dari ketiga variasi kulit pisang yang menghasilkan volume biogasterbanyak adalah campuran kotoran sapi dan kulit pisang raja (R3) (1:4) pada hari ke-9 yaitusebanyak 409 mL, hal ini disebabkan karena pada kulit pisang raja memiliki kadar $\mathrm{C} / \mathrm{N}$ lebih rendah dibandingkan kulit pisang ambon dan kulit pisang kepok, dimana salah satu faktor yang mempengaruhi proses fermentasi biogas adalah kadar $\mathrm{C} / \mathrm{N}$, dimana kadar $\mathrm{C} / \mathrm{N}$ tiap komponen haruslah berkisar antara 20-30 sehingga unsur-unsur nutrisi yang dibutuhkan oleh mikroba pembentuk biogas harus tersedia secara seimbang(Wiratmana, 2012).

\section{Derajat Keasaman (pH)}

Derajat keasaman $(\mathrm{pH})$ merupakan parameter penting yang mempengaruhi pertumbuhan mikroba selama fermentasi anaerobik. $\mathrm{pH}$ digester harus dijaga dalam kisaran 6,8-7,2 (Yadvika, 2004). Pengukuran $\mathrm{pH}$ dilakukan diawal sebelum proses fermentasi dan diakhir setelah proses fermentasi (15 hari), yaitu pengukuran $\mathrm{pH}$ awal dilakukan sebelum bahan dimasukkan ke dalam bioreaktor terlebih dahulu dilakukan pengecekan $\mathrm{pH}$ awal, kemudian untuk $\mathrm{pH}$ akhir dilakukan pada akhir penelitian dilakukan pengecekan $\mathrm{pH}$ akhir setelah proses fermentasi anaerob.

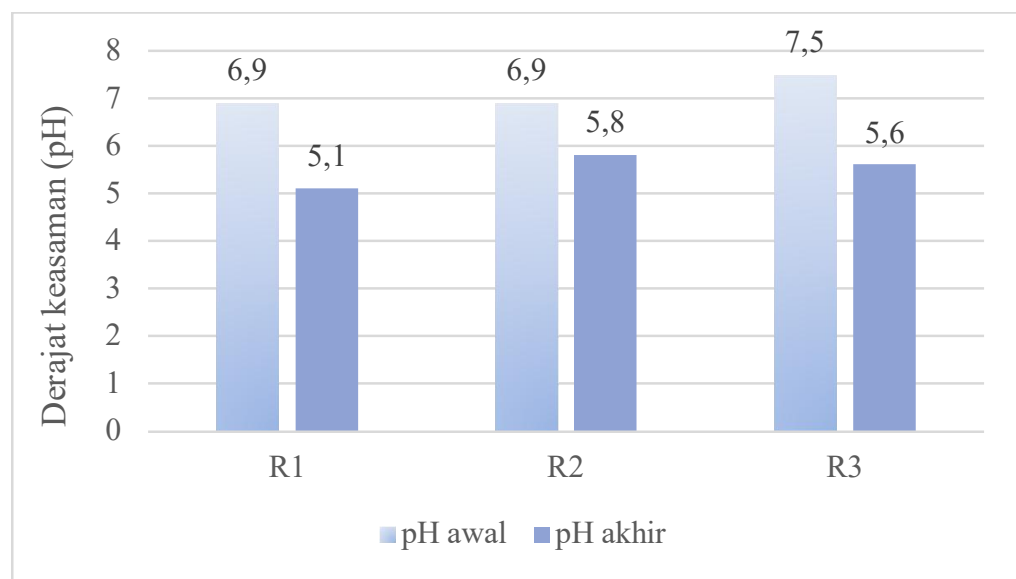

Gambar 3. Pengaruh Nilai pH awal dan pH akhir terhadap Proses pembentukan Biogas 
Berdasarkan hasil pengamatan pada gambar 3 menunjukkan perubahan $\mathrm{pH}$ yang terjadi sebelum dan sesudah proses fermentasi anaerob. Pada R1 (kulit pisang ambon) mempunyai nilai pH awal 6,9 dan pH akhir 5,1. Pada R2 (kulit pisang kepok) mempunyai nilai pH awal 6,9 dan pH akhir 5,8. Pada R3 (kulit pisang raja) mempunyai nilai $\mathrm{pH}$ awal 7,5 dan $\mathrm{pH}$ akhir 5,6. Hal ini berarti ketiga bioreaktor menunjukkan pH akhir dalam keadaan asam. Kondisi substrat dengan keadaan sangat asam atau nilai pH yang rendah akan menyebabkan proses produksi gas metan terhenti karena kondisi mikroba dalam bioreaktor tidak memperoleh nutrisi dengan baik sehingga mikroba tidak dapat tumbuh dengan maksimum. Menurut Khaerunnisa (2013) pertumbuhan bakteri penghasil gas metana akan baik bila $\mathrm{pH}$ berada pada keadaan basa yaitu 6,5 sampai 7. Apabila $\mathrm{pH}$ dibawah 6,5 maka aktivitas bakteri metanogen akan menurun dan apabila dibawah 5,0 maka fermentasi akan terhenti.

Proses fermentasi dapat berlangsung dalam keadaan normal dan anaerobik, sehingga $\mathrm{pH}$ akan secara otomatis berkisar antara 7-8,5. Jika $\mathrm{pH}$ lebih tinggi dari 8,5 akan mengakibatkan pengaruh yang negatif pada populasi bakteri metanogen, sehingga akan mempengaruhi laju pembentukan biogas dalam reaktor. dimana hal ini sudah sesuai dengan R3 (kulit pisang raja) memiliki $\mathrm{pH}$ awal 7,5. Dari pernyataan diatas dapat disimpulkan bahwa proses fermentasi masih dapat berjalan dengan kondisi $\mathrm{pH}$ 6,8-8,5 dengan kondisi terbaik berada pada kisaran $\mathrm{pH}$ 7. Produksi asam yang berlebihan dapat menghambat bakteri metanogen, karena Bakteri metanogen sangat sensitif terhadap konsentrasi asam di dalam digester dan pertumbuhannya dapat dihambat oleh kondisi asam (Verma, 2002).

\section{Uji nyala}

Uji nyala merupakan pengujian yang dilakukan untuk mengetahui kandungan gas metana yang dihasilkan dari proses pembuatan biogas. Uji nyala ini dilakukan dengan cara membakar langsung ujung selang atau ujung selang tersebut didekatkan pada sumber api. Pada uji nyala R1 (kulit pisang ambon) menghasilkan api berwarna biru kemerahan, hal ini menunjukkan bahwa api yang dihasilkan dari R1 memiliki kandungan metana yang sedikit. Hal ini sesuai dengan pernyataan Ayu (2018), bahwa kandungan gas metana yang masih sangat sedikit dan mengandung lebih banyak gas-gas pengotor lainnya maka warna api yang dihasilkan adalah cenderung kemerah-merahan. Menurut Uwar dkk (2012) bahwa Kadar $\mathrm{CO}_{2}$ juga berpengaruh terhadap pembakaran $\mathrm{CH} 4$. Pembakaran bahan bakar tanpa $\mathrm{CO} 2$ akan menghasilkan api berwarna biru sedangkan dengan penambahan $\mathrm{CO}_{2}$ akan menghasilkan api berwarna kuning kemerahan yang menunjukkan pembakaran tidak sempurna.

Pada Uji nyala R2 (kulit pisang kepok) menghasilkan nyala api berwarna biru, kemudian pada R3 (kulit pisang raja) juga menghasilkan nyala api berwarna biru yang menandakan bahwa terdapat gas metana pada uji nyala R2 dan R3. Hal ini sesuai dengan penelitian Fairuz (2015) yang menyatakan nyala api yang berwarna biru menunjukkan bahwa kandungan metana sangat tinggi dibandingkan dengan kandungan gas lain selain metana. Menurut Ilhsan (2013) bahwa uji nyala yang menghasilkan warna biru menunjukkan adanya unsur metana di dalam biogas dan diperkirakan kandungan metana dalam gas sekitar $45 \%$

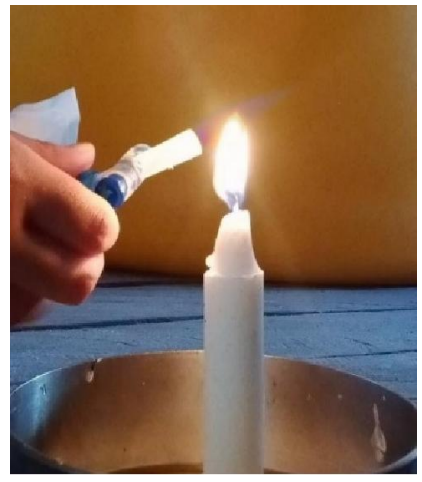

Uji nyala biogas (R1)

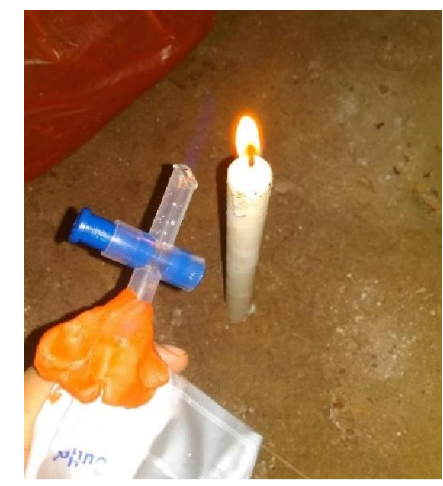

Uji nyala biogas (R2)

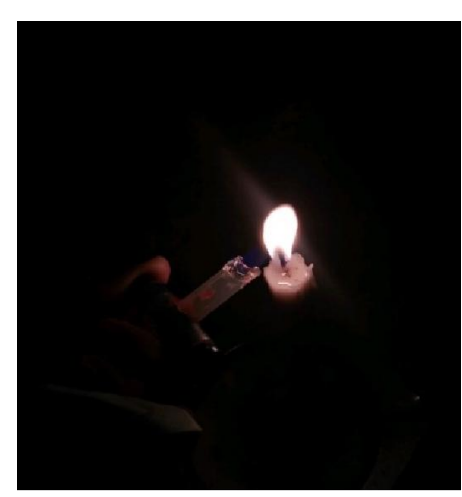

Uji nyala biogas (R3)

Gambar 4. Gambar Uji Nyala gas yang di hasilkan dengan variasi perbandingan jenis kulit pisang dan Kotoran sapi

\section{Kesimpulan}

Dari penelitian ini dapat disimpulkan bahwa pembuatan biogas dari campuran kotoran sapi dan beberapa jenis kulit pisang (ambon, kepok dan raja), yang memiliki volume biogas terbanyak adalah campuran kotoran 
sapi dan kulit pisang raja (1:4) pada hari ke-9 yaitu sebanyak $409 \mathrm{~mL}$. Dengan nilai $\mathrm{pH}$ awal untuk semua variasi kulit pisang berada pada range 6,9-7,5 dan untuk nilai $\mathrm{pH}$ akhir berada pada range 5,1-5,8 hal ini berarti ketiga bioreaktor menunjukkan $\mathrm{pH}$ akhir dalam keadaan asam. Selain itu di dapat hasil uji nyala pada R1 (kulit pisang ambon) menghasilkan nyala api biru kemerahan kemudian pada R2 (kulit pisang kepok) dan R3 (kulit pisang raja) menghasilkan nyala api biru, berdasarkan hasil peneletian yang sudah dilakukan dapat ditarik kesimpulan bahwa produksi biogas terbaik diperoleh dari variasi kulit pisang raja.

\section{Ucapan Terima Kasih}

Penulis mengucapkan terima kasih atas Lembaga Penelitian dan Pengabdian kepada Masyarakat (LPPM) Institut Teknologi Nasional (ITN) Malang atas dukungan finansialnya pada penelitian ini.

\section{Daftar Pustaka}

Bahri, Syamsul., dkk. 2018. Pembuatan Bioetanol dari Kulit Pisang Kepok dengan Cara Fermentasi Menggunakan Ragi Roti. Aceh : Universitas Malikusaleh

Fitri, Medya Ayunda \& Dhaniswara, Trisna Kumala. 2018. Pemanfaatan Kotoran Sapi dan Sampah Sayur pada Pembuatan Biogas dengan Fermentasi Sampah Sayuran. Sidoarjo : Universitas Nadlatul Ulama. Vol.4 No. 1

Herawati, Dewi Astuti. 2010. Pengaruh Pretreatment Jerami Padi pada Produksi Biogas dari Jerami Padi dan Sampah Sayur Sawi Hijau Secara Batch. Surakarta: Universitas Setia Budi. Vol. 4 No.1.

Irawan, Dwi \& Suwanto, Eko. 2016. Pengaruh EM-4 (Effective Microorganisme) Terhadap Produksi Biogas Menggunakan Bahan Baku Kotoran Sapi. Lampung: Universitas Muhammadiyah Metro. Vol. 5 No. 1.

Lestari, Silvia., dkk. 2016. Analisis Jumlah Bakteri Anaerob dan Proporsi Gas Metana pada Proses Pemebentukan Biogas dari Feses Sapi Perah dalam Tabung Hungate. Bandung : Universitas Padjajaran

Prihutama, Faiz Akbar., dkk. 2017. Pemanfaatan Biogas sebagai Energi Alternatif Ramahlingkungan Daerah Desa Monggol, Kabupaten Gunungkidul, Yogyakarta. Yogyakarta : Universitas Pembangunan Nasional"Veteran" Yogyakarta.

Retno, Dyah Tri. 2016. Pembuatan Bioetanol dari Kulit Pisang. Yogyakarta: Universitas Pembangunan Nasional"Veteran" Yogyakarta.ISSN 1693 - 4393

Suyitno, dkk. 2010. Teknologi Biogas. Yogyakarta : Graha Ilmu

Wiratmana, I Putu Awing., dkk. 2012. Studi Eksperimental Pengaruh Variasi Bahan Kering Terhadap Produksi dan Nilai Kalor Biogas Kotoran Sapi. Bali : Universitas Udayana 